\title{
Teknik Penyemprotan Pestisida pada Pertanaman Mentimun : Pengaruhnya Terhadap Tingkat Penutupan dan Sebaran Droplet
}

\author{
Spraying Technique of Pesticide on Cucumber : Its effect on Coverage and \\ Distribution of Droplets
}

Tonny K. Moekasan

Diterima 02 Agustus 2017/ Disetujui 15 Oktober 2018

\begin{abstract}
Spraying technique of pesticides that are commonly carried out by cucumber farmers in Indonesia is very diverse, so it is needed to be evaluated to find out the right way to spray. This experiment aimed to determine the effect of nozzle swing on the level of coverage and distribution of droplets. In addition, it is also to find out the effectiveness of pesticides used in pests and diseases control in cucumber cultivation. The experiment was carried out at Margahayu Experimental Garden ( \pm 1250 m asl.), Indonesian Vegetable Research Institute in Lembang, West Java, from July to October 2015. The experiment was arranged using paired comparisons and each treatment was repeated four times. The treatment tested is how to swing the nozzle with the position: (A) above the plant canopy facing down and moving forward and $(B)$ below and swinging towards the plant at an angle of $45^{\circ}$. Results showed that the second nozzle swinging method (B) gave a higher level of coverage and distribution of droplets than that produced by the first nozzle swinging method, so the pesticide efficacy in treatment $B$ was also higher.
\end{abstract}

Keywords: efficacy, financial analysis, pesticide, spray volume

\begin{abstract}
ABSTRAK
Cara penyemprotan pestisida yang umum dilakukan oleh petani mentimun di Indonesia sangat beragam, sehingga perlu dievaluasi untuk mengetahui cara penyemprotan yang tepat. Percobaan ini bertujuan mengetahui pengaruh ayunan nozzle terhadap tingkat tingkat penutupan dan sebaran droplet. Selain itu juga untuk mengetahui keefektipan pestisida yang digunakan terhadap hama dan penyakit pada tanaman mentimun. Percobaan dilaksanakan di Kebun Percobaan Margahayu ( $\pm 1250 \mathrm{~m} \mathrm{dpl}$ ), Balai Penelitian Tanaman Sayuran di Lembang, Jawa Barat, mulai bulan Juli sampai dengan Oktober 2015. Percobaan disusun menggunakan petak berpasangan (paired comparison) dan tiap pasangan perlakuan diulang empat kali. Perlakuan yang diuji ialah cara mengayunkan nozzle dengan posisi: (A) di atas tajuk tanaman menghadap ke bawah dan digerakkan ke depan dan (B) dari bawah dan diayunkan ke arah tanaman dengan sudut $45^{\circ}$. Hasil percobaan menunjukkan bahwa cara mengayunkan nozzle yang ke-2 (B) menghasilkan tingkat penutupan daun oleh larutan semprot dan sebaran droplet yang lebih tinggi daripada yang dihasilkan oleh cara mengayunkan nozzle yang ke-1 (A), sehingga keefektipan pestisida pada perlakuan B juga lebih tinggi.
\end{abstract}

Kata kunci: analisis finansial, keefektipan, pestisida, volume semprot 


\section{PENDAHULUAN}

Petani mentimun pada umumnya mengandalkan penggunaan pestisida untuk mengatasi masalah hama dan penyakit. Praktik tersebut dilakukan secara intensif dan tanpa mengikuti kaidah yang benar. Akibatnya, kandungan residu pestisida pada buah mentimun adalah yang tertinggi dibandingkan dengan tomat, paprika, kentang, bawang bombay, wortel dan kubis (Kostik et al., 2014). Data hasil survei di Kazakhstan menunjukkan bahwa 59\% sampel buah mentimun mengandung 29 jenis pestisida dan 10 jenis di antaranya tidak terdaftar di negara tersebut. Sementara 29\% sampel mengandung residu pestisida di atas ambang batas yang telah ditetapkan (Lozowicka et al., 2015). Penggunaan pestisida secara intensif tidak selalu mampu menekan serangan hama dan penyakit. Win (2010) melaporkan bahwa kerusakan tanaman masih sebesar 35\% meskipun segala usaha termasuk penggunaan pestisida telah dilakukan. Lebih lanjut, dilaporkan bahwa hal itu terjadi akibat kesalahan dalam penyemprotan pestisida.

Teknik penyemprotan pestisida berpengaruh terhadap kualitas penyemprotan. Idealnya, pestisida yang disemprotkan ke tanaman tersebar merata dan meliputi permukaan tanaman di mana hama berada (Cavalieri et al., 2015; Davide, 2013). Faktorfaktor penting yang berpengaruh terhadap efikasi pestisida antara lain ialah deposit dan tingkat penutupan droplet yang akan menjamin dosis yang mematikan terhadap sasaran (Cerruto et al., 2013), daya menempel atau adesi droplet (Sugiura et al., 2011), dan retensi atau daya tampung permukaan daun (Forster et al., 2012). Penyemprotan pestisida yang efisien mampu menjamin sebaran droplet yang merata pada tanaman, termasuk pada sisi bawah daun. Menurut Sun et al. (2015), salah satu faktor yang mempengaruhi hasil penyemprotan ialah pergerakan alat semprot, karena faktor itu juga menentukan penyebaran dan tingkat penutupan larutan semprot.

Informasi tentang cara penyemprotan pestisida oleh petani mentimun di Indonesia sangat terbatas. Pengamatan di lapangan diketahui bahwa cara penyemprotan pestisida yang umum dilakukan oleh petani di Indonesia adalah dengan mengayunkan nozzle dari bawah ke atas tajuk dengan nozzle menghadap ke atas, selanjutnya nozzle digerakkan dari atas tajuk ke bawah dengan nozzle menghadap ke bawah. Praktik demikian membutuhkan volume semprot yang lebih tinggi dan melebihi daya tampung permukaan daun dalam menerima larutan semprot. Hal itu mengakibatkan larutan semprot banyak yang terjatuh di atas tanah sehingga mencemari lingkungan. Menurut Fourie et al. (2009), deposisi droplet meningkat dengan meningkatnya volume semprot, tetapi hanya sampai pada titik run off tercapai, setelah itu menurun.

Oleh karena itu cara penyemprotan yang tepat perlu diketahui dengan menguji pengaruh ayunan dua arah nozzle (nozzle di atas tajuk mengarah ke bawah dan posisi nozzle dari bawah menghadap ke tanaman dengan sudut $45^{\circ}$ ) terhadap sebaran droplet dan efikasi pestisida. Hipotesis yang diajukan adalah teknik penyemprotan pestisida dengan posisi nozzle menghadap tanaman dari bawah dengan sudut $45^{\circ}$ akan menghasilkan droplet yang tersebar secara merata sehingga keefektipan pestisida terhadap hama dan penyakit yang menyerang mentimun akan lebih efektif.

\section{BAHAN DAN METODE}

Percobaan dilaksanakan di Kampung Margahayu dengan ketinggian \pm 1.250 meter di atas permukaan laut ( $\mathrm{m} \mathrm{dpl}$ ) Balai Penelitian Tanaman Sayuran di Lembang, Jawa Barat mulai bulan Juli sampai bulan Oktober 2015 . Pada percobaan ini digunakan petak berpasangan dan tiap pasangan diulang empat kali (Chiarappa, 1971). Pasangan perlakuan yang diuji ialah (A) ayunan nozzle digerakkan ke depan menghadap ke bawah di atas tajuk tanaman dan (B) ayunan nozzle dari bawah diarahkan ke tanaman dengan sudut $45^{\circ}$ (Gambar 1).

Pada percobaan ini digunakan mentimun varietas Bandana yang ditanam dengan sistem baris ganda dengan jarak tanam $30 \mathrm{~cm} \times 70 \mathrm{~cm}$, dengan jarak antar petak perlakuan $1 \mathrm{~m}$. Ukuran masing-masing petak percobaan $2.5 \mathrm{~m} \times 6 \mathrm{~m}=15 \mathrm{~m}^{2}$, dengan populasi tanaman mentimun sebanyak 120 tanaman. Pada setiap petak perlakuan dipagari dengan 2 baris tanaman jagung yang ditanam 1.5 bulan sebelum tanaman mentimun ditanam dengan tujuan untuk menghindari pengaruh perlakuan. 


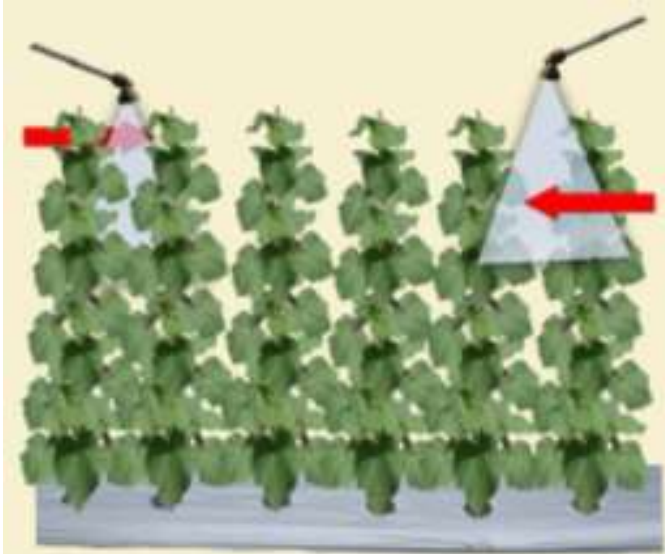

Perlakuan A

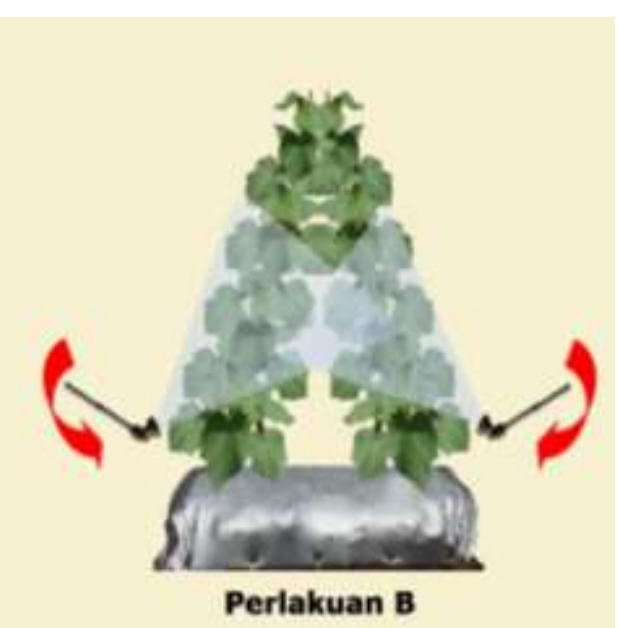

Perlakuan B

Gambar 1. Perlakuan A (ayunan nozzle digerakkan ke depan menghadap ke bawah di atas tajuk tanaman) dan perlakuan B (ayunan nozzle dari bawah diarahkan ke tanaman dengan sudut $\left.45^{\circ}\right)$.

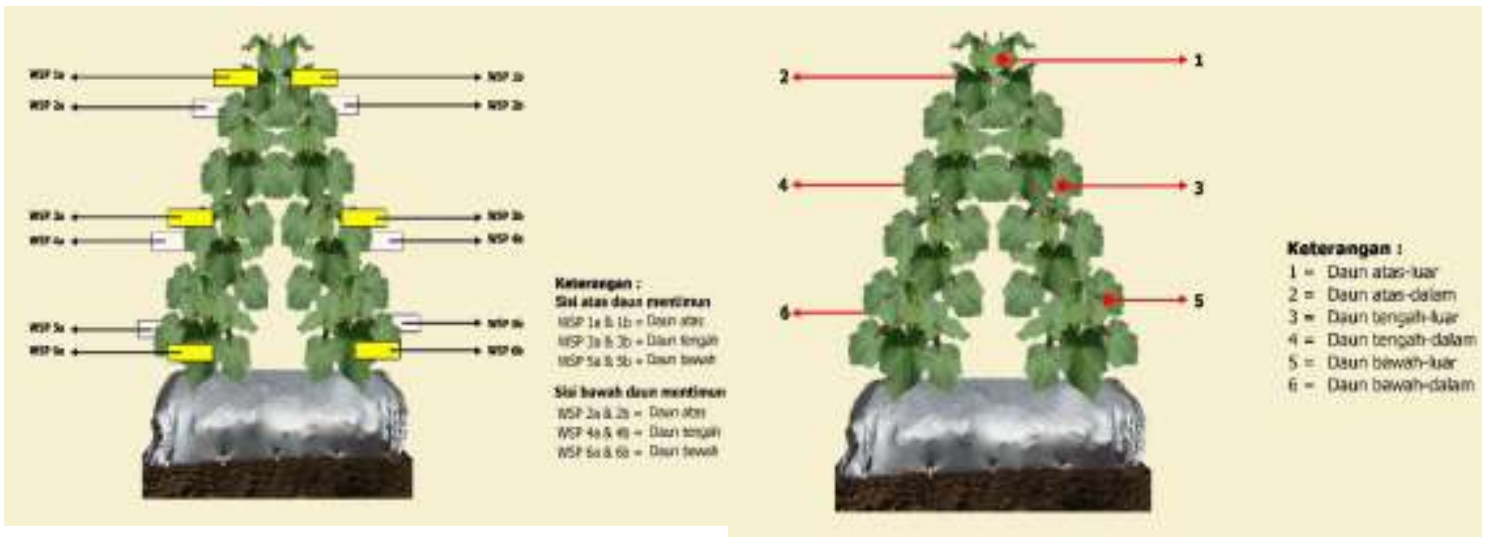

Gambar 2. Letak WSP pada tanaman mentimun (kiri) dan daun contoh untuk menaksir penyebaran larutan semprot (kanan).

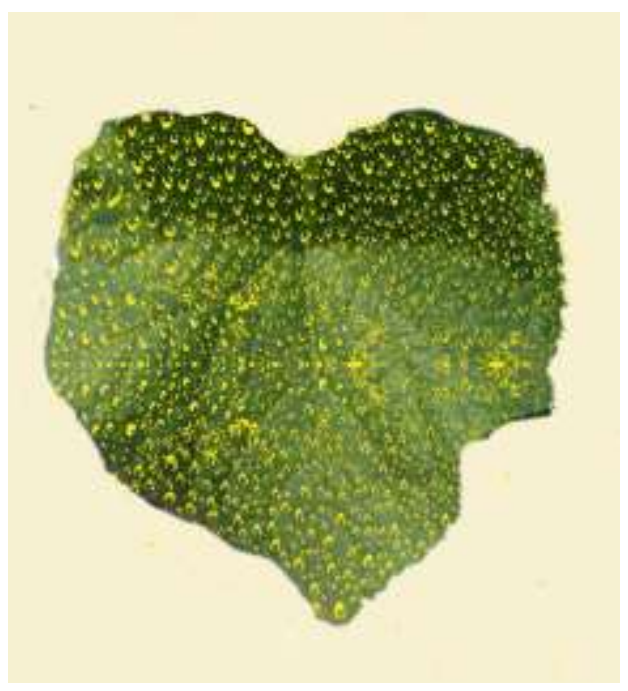

Gambar 3. Kriteria penyebaran droplet yang merata 
Pemupukan pada tanaman mentimun dilakukan sebagai berikut : (1) satu minggu sebelum tanam diberikan pupuk kandang sebanyak 10 ton ha-1, pupuk $\mathrm{N}\left(100 \mathrm{~kg} \mathrm{ha}^{-1}\right)$, $\mathrm{P}_{2} \mathrm{O}_{5}\left(70 \mathrm{~kg} \mathrm{ha}^{-1}\right), \mathrm{K}_{2} \mathrm{O}\left(120 \mathrm{~kg} \mathrm{ha}^{-1}\right)$ yang dihamparkan di atas bedengan pertanaman dan diaduk secara merata, (2) pupuk susulan diberikan pada umur 3 minggu setelah tanam sebanyak $60 \mathrm{~kg} \mathrm{ha}^{-1} \mathrm{~N}$.

Untuk menaksir tingkat penutupan droplet pada pertanaman, pada percobaan ini digunakan kertas peka air (water-sensitive paper/ WSP) yang berukuran $75 \mathrm{~mm} \times 25 \mathrm{~mm}$. Kertas peka air yang digunakan ini diproduksi oleh Syngenta Crop Protection AG, Basel, Switzerland (Salyani et al., 2013). Pemasangan WSP pada tanaman mentimun seperti disajikan pada Gambar 2. Penggunaan WSP dilakukan pada 4, 6, dan 8 minggu setelah tanam.

Menurut (Schleier et al., 2010), untuk mengetahui penyebaran droplet pada pertanaman dapat digunakan penyemprotan larutan fluorescens $\left(10 \mathrm{~g} \mathrm{~L}^{-1}\right)$. Oleh karena itu pada percobaan ini, pada saat tanaman mentimun berumur 4 , 6, dan 8 minggu dilakukan penyemprotan larutan fluorescens $\left(10 \mathrm{~g} \mathrm{~L}^{-1}\right)$. Setelah dilakukan penyemprotan fluorescens pada setiap petak perlakuan dilakukan pengamatan pada daun contoh yang terletak di daun atas luar, daun atas dalam, daun tengah luar, daun tengah dalam, daun bawah luar, dan daun bawah dalam masingmasing sebanyak 3 helai. Letak daun tersebut digambarkan pada Gambar 2.

Penyemprotan pestisida menggunakan penyemprot punggung elektrik (electric knapsack sprayer) merek Swan B-16 yang berkapasitas 161 . Nozzle yang digunakan ialah hollow cone 4 lubang berbahan kuningan merek Swan. Penyemprotan pestisida dilakukan mulai tanaman mentimun berumur 21 hari setelah tanam diulang setiap 5 hari. Bahan aktif pestisida yang digunakan ialah abamektin + klorotalonil dan spinetoram + klorotalonil, yang disemprotkan secara bergiliran setiap tiga minggu. Peubah yang diamati ialah :

(1) Volume semprot yang digunakan pada setiap petak perlakuan pada setiap kali penyemprotan, dilakukan dengan menakar volume semprot yang digunakan pada setiap petak perlakuan.
(2) Tingkat penutupan droplet pada WSP yang ditaksir menggunakan aplikasi berbasis android Snap Card yang dikeluarkan oleh Government of Western Australia, Department of Agriculture and Food. Persentase tingkat penutupan semprot dihitung menggunakan rumus sebagai berikut :

$$
\begin{aligned}
& \mathrm{PL}=\frac{\sum(\mathrm{n} \times \mathrm{v})}{\mathrm{N} \times \mathrm{Z}} \times 100 \% \\
& \text { PL : Persentase tingkat penutupan } \\
& \text { semprot }(\%) \\
& \mathrm{v} \text { : Nilai (skor) tingkat penutupan } \\
& \text { droplet berdasarkan luas WSP } \\
& \text { yang terpapar larutan semprot, } \\
& \text { yaitu : } \\
& 0 \text { : Tidak ada droplet pada WSP } \\
& 1 \text { : Luas tingkat penutupan droplet } \\
& \text { pada } W S P>0-\leq 20 \% \\
& 3 \text { : Luas tingkat penutupan droplet } \\
& \text { pada } W S P>20-\leq 40 \% \\
& 5 \text { : Luas tingkat penutupan droplet } \\
& \text { pada } W S P>40 \text { - } \leq 60 \% \\
& 7 \text { : Luas tingkat penutupan droplet } \\
& \text { pada } W S P>60-\leq 80 \% \\
& 9 \text { : Luas tingkat penutupan droplet } \\
& \text { pada } W S P>80 \% \\
& \mathrm{n} \text { : Jumlah WSP yang memiliki } \\
& \text { nilai } \mathrm{v} \text { (tingkat penutupan } \\
& \text { semprot) yang sama. } \\
& \mathrm{Z} \text { : Nilai (skor) tertinggi }(\mathrm{v}=9) \text {. } \\
& \mathrm{N} \text { : Jumlah WSP yang diamati }
\end{aligned}
$$

(3) Tingkat penutupan droplet ditetapkan dengan cara mengambil daun atas luar, daun atas dalam, daun tengah luar, daun tengah dalam, daun bawah luar, dan daun bawah dalam masing-masing sebanyak 3 helai per petak setelah penyemprotan fluorescens. Untuk mengetahui penyebaran tingkat penutupan droplet, setelah penyemprotan fluorescens pengamatan dengan cara mengambil masing-masing sebanyak 3 daun atas luar, daun atas dalam, daun tengah luar, daun tengah dalam, daun bawah luar, dan daun bawah dalam. Daun-daun tersebut dibawa ke ruangan gelap untuk diamati penyebaran droplet fluorescens di bawah lampu ultra violet. Kriteria penyebaran droplet yang merata ialah jika droplet tersebar secara merata pada bagian pucuk, tengah dan pangkal daun mentimun 
seperti yang disajikan pada Gambar 3 . Untuk mengetahui persentase penyebaran droplet dihitung dengan rumus :

$$
P=\frac{a}{a+b} \times 100 \%
$$

Keterangan:

$\mathrm{P}=$ Tingkat penutupan droplet yang merata per petak.

$\mathrm{a}=$ Jumlah daun yang droplet-nya merata per petak.

$\mathrm{b}=$ Jumlah daun yang droplet-nya tidak merata per petak.

Pengamatan serangan hama dan penyakit yang menyerang tanaman mentimun dilakukan pada tanaman contoh mulai umur 21 hari setelah tanam dengan interval 7 hari. Pada setiap petak perlakuan diambil sebanyak 10 tanaman contoh yang ditetapkan secara acak sistematis. Macam pengamatan pada setiap tanaman contoh ialah sebagai berikut :

(1) Populasi hama, yaitu dihitung jumlah individu hama per tanaman contoh.

(2) Intensitas serangan penyakit, menaksir nilai (skor) luas serangan penyakit pada daun dan intensitas serangan penyakit dihitung menggunakan rumus sebagai berikut :

$$
P=\frac{\sum(\mathrm{nxv})}{\mathrm{N} \times \mathrm{Z}} \times 100 \%
$$

$\mathrm{P}$ : Intensitas kerusakan tanaman (\%)

$\mathrm{v}$ : Nilai (skor) luas serangan penyakit berdasarkan luas daun terserang pada setiap tanaman contoh, yaitu :

0 : Tidak ada serangan

$1:$ Luas daun terserang $>0-\leq 10 \%$

2 : Luas daun terserang $>10-\leq 20 \%$

3 : Luas daun terserang $>20-\leq 40 \%$

$4:$ : Luas daun terserang $>40-\leq 60 \%$

5 : Luas daun terserang $>60 \%$

$\mathrm{n}$ : Jumlah tanaman yang memiliki nilai $\mathrm{v}$ (luas daun terserang) yang sama.

$\mathrm{Z}$ : Nilai (skor) tertinggi $(\mathrm{v}=5)$.

$\mathrm{N}$ : Jumlah tanaman yang diamati.

(3) Hasil panen, bobot buah sehat, bobot buah terserang hama dan penyakit per petak perlakuan masing-masing ditimbang.
(4) Dihitung volume semprot, jenis pestisida, dan biaya penggunaan pestisida untuk masing-masing perlakuan.

Menurut Chiarappa (1971), jika hasil pengamatan menunjukkan adanya perbedaan antar perlakuan, maka dilakukan uji lanjut menggunakan uji-t pada taraf 5\%. Oleh karena itu, pada percobaan ini jika ada perbedaan antar perlakuan dilakukan uji-t pada taraf $5 \%$.

Menurut Basuki (2009), salah satu alat untuk menguji kelayakan ekonomis suatu teknologi dapat dilakukan dengan melakukan analisi anggaran parsial. Pada percobaan ini data yang dikumpulkan untuk keperluan analisis anggaran parsial ialah : (1) penjualan hasil panen mentimun, (2) upah penyemprotan pestisida, dan (3) biaya pembelian pestisida. Data-data tersebut dianalisis menggunakan teknik Analisis Anggaran Parsial menurut Basuki (2009). Rumus analisis anggaran parsial adalah sebagai berikut :

$$
\begin{aligned}
\Delta \mathrm{NI} & =\Delta \mathrm{TR}-\Delta \mathrm{VC} \\
\mathrm{R} & =\Delta \mathrm{NI} / \Delta \mathrm{VC}
\end{aligned}
$$

Keterangan:

TR : total penerimaan hasil panen tiap perlakuan $(\mathrm{Rp} / \mathrm{ha})=$ hasil $(\mathrm{kg} / \mathrm{ha}) \mathrm{x}$ harga hasil $(\mathrm{Rp} / \mathrm{kg})$

VC : total biaya berubah tiap perlakuan (Rp/ha), yaitu kuantitas input yang digunakan (unit/ha) $\mathrm{x}$ harga input (Rp/ha)

NI : pendapatan, yaitu penerimaan total - total biaya berubah

$\Delta \quad: \quad$ selisih, perbedaan atau perubahan

$\Delta \mathrm{NI}$ : selisih pendapatan bersih budidaya mentimun dengan teknik penyemprotan pada perlakuan A dengan pendapatan bersih teknik penyemprotan dengan perlakuan $\mathrm{B}$

$\Delta \mathrm{TR}$ : selisih nilai hasil panen budidaya mentimun dengan teknik penyemprotan perlakuan A dengan nilai hasil panen dengan teknik penyemprotan perlakuan B

$\Delta \mathrm{VC}$ : selisih biaya variabel teknik penyemprotan perlakuan A dengan biaya variabel teknik penyemprotan B

$\mathrm{R} \quad$ : rate of return (tingkat pengembalian) Kriteria pengambilan keputusan : 
1. Teknik penyemprotan tersebut akan ditolak, jika nilai NI tetap sama atau lebih rendah

2. Teknik penyemprotan tersebut akan diterima dan mempunyai peluang untuk diadopsi, jika nilai NI naik dan VC tetap sama atau lebih rendah

3. Teknik penyemprotan tersebut mempunyai peluang untuk diadopsi, jika nilai NI dan VC naik, serta $\mathrm{R} \geq 1.0$

4. Teknik penyemprotan tersebut secara ekonomi menarik untuk diadopsi jika mempunyai nilai NI dan $\mathrm{R}$ yang semakin tinggi

\section{HASIL DAN PEMBAHASAN}

\section{Volume Semprot}

Salah satu faktor yang harus dipertimbangkan dalam menetapkan volume semprot ialah retensi tanaman (crop retention capacity), yaitu kemampuan maksimum pertanaman untuk menampung larutan semprot dalam bentuk droplet, tanpa ada larutan semprot yang menetes ke bawah (run off). Menurut Gaskin et al. (2000), faktor yang berpengaruh terhadap retensi larutan semprot ialah arsitektur tanaman (kanopi dan bentuk), orientasi daun, kekasaran makro dan mikro permukaan daun serta hydrophobicity permukaan daun.

Hasil penelitian Gaskin et al. (2000) menyatakan bahwa retensi tanaman mentimun tertinggi tercapai pada volume semprot sebesar $500 \mathrm{~L} \mathrm{ha}^{-1}$. Informasi mengenai volume semprot untuk tanaman mentimun di Indonesia belum tersedia, tetapi dalam Djojosumarto (2008) disebutkan bahwa volume penyemprotan untuk tanaman tomat (yang mendekati habitus tanaman mentimun) pada penyemprotan menggunakan penyemprot punggung adalah sebesar $500 \mathrm{~L}$ $\mathrm{ha}^{-1}$. Volume semprot pada kedua perlakuan yang diuji dari penyemprotan pertama sampai terakhir masing-masing berkisar antara 188.33-325.00 L hä dan 308.33-445.00 $\mathrm{L} \mathrm{ha}^{-1}$. Dengan demikian, volume semprot yang digunakan pada kedua perlakuan dalam percobaan ini masih memenuhi syarat, karena besarnya di bawah nilai tersebut (Tabel 1).

\section{Tingkat Penutupan Droplet}

Tingkat penutupan droplet (coverage) yaitu banyaknya droplet yang menutupi bidang penyemprotan, merupakan salah satu faktor yang menentukan kualitas penyemprotan pestisida (Shi et al., 2011; Yang et al., 2012; Sun et al., 2015). Menurut Foque dan Nuyttens (2011), cara menyebarkan larutan semprot yang baik pada seluruh permukaan tanaman berkaitan erat dengan hasil tingkat penutupan droplet pada bidang penyemprotan.

Data tingkat penutupan droplet pada tanaman mentimun disajikan pada Tabel 2. Pada empat minggu setelah tanam, teknik penyemprotan dengan ayunan nozzle digerakkan ke depan menghadap ke bawah di atas tajuk tanaman hanya mampu menghasilkan tingkat penutupan droplet yang tinggi pada daun atas sisi atas saja. Rupanya penyemprotan dengan cara tersebut tidak mampu menjangkau daun tengah dan daun bawah pada sisi atas maupun sisi bawah secara optimum. Terbukti dengan tingkat penutupannya pada bagian tanaman tersebut lebih rendah daripada hasil teknik penyemprotan dengan ayunan nozzle dari bawah diarahkan ke tanaman dengan sudut $45^{0}$. Kondisi serupa terjadi pula pada penyemprotan enam minggu setelah tanam.

Pada delapan minggu setelah tanam, tingkat penutupan droplet yang terbaik dihasilkan oleh teknik penyemprotan ayunan nozzle digerakkan ke depan menghadap ke bawah di atas tajuk tanaman, hanya pada daun atas sisi atas, sedangkan teknik penyemprotan dengan ayunan nozzle dari bawah diarahkan ke tanaman dengan sudut $45^{\circ}$ hanya menghasilkan tingkat penutupan droplet terbaik pada daun bawah sisi atas dan daun atas sisi bawah. Pada umur tersebut, tanaman mentimun sudah mencapai ketinggian $1.5 \mathrm{~m}$ dan daunnya cukup lebat, sehingga larutan semprot sulit menjangkau daun-daun yang berada di dalam kanopi tanaman. 
Tabel 1 . Volume semprot yang digunakan satu musim tanam mentimun

\begin{tabular}{lcc}
\hline \multicolumn{1}{c}{ Perlakuan } & $\begin{array}{c}\text { Per petak } \\
\left(\mathrm{ml}^{-1} 15 \mathrm{~m}^{2}\right)\end{array}$ & $1 \mathrm{ha}^{-1}$ \\
\hline $\begin{array}{l}\text { Ayunan nozzle digerakkan ke depan menghadap ke bawah di } \\
\text { atas tajuk tanaman }\end{array}$ & $282.50-487.50$ & $\begin{array}{c}188.33- \\
325.00\end{array}$ \\
$\begin{array}{l}\text { Ayunan nozzle dari bawah diarahkan ke tanaman dengan } \\
\text { sudut 45 }\end{array}$ & $462.50-667.50$ & $\begin{array}{c}308.33- \\
445.00\end{array}$ \\
\hline
\end{tabular}

Tabel 2. Tingkat penutupan droplet (\%) pada daun mentimun umur 4, 6, dan 8 minggu setelah tanam

\begin{tabular}{|c|c|c|c|c|c|c|}
\hline \multirow{3}{*}{ Perlakuan } & \multicolumn{6}{|c|}{ Pada Umur 4 Minggu Setelah Tanam } \\
\hline & \multicolumn{3}{|c|}{ Sisi Atas Daun } & \multicolumn{3}{|c|}{ Sisi Bawah Daun } \\
\hline & $\begin{array}{c}\text { Daun } \\
\text { Atas }\end{array}$ & $\begin{array}{c}\text { Daun } \\
\text { Tengah }\end{array}$ & $\begin{array}{c}\text { Daun } \\
\text { Bawah }\end{array}$ & $\begin{array}{c}\text { Daun } \\
\text { Atas }\end{array}$ & $\begin{array}{c}\text { Daun } \\
\text { Tengah }\end{array}$ & $\begin{array}{c}\text { Daun } \\
\text { Bawah }\end{array}$ \\
\hline $\begin{array}{l}\text { Ayunan nozzle digerakkan } \\
\text { ke depan menghadap ke } \\
\text { bawah di atas tajuk } \\
\text { tanaman }\end{array}$ & $87.5 \mathrm{~b}$ & $38.9 \mathrm{a}$ & $36.1 \mathrm{a}$ & $16.7 \mathrm{a}$ & $11.1 \mathrm{a}$ & $13.9 \mathrm{a}$ \\
\hline $\begin{array}{l}\text { Ayunan nozzle dari bawah } \\
\text { diarahkan ke tanaman } \\
\text { dengan sudut } 45^{\circ}\end{array}$ & $58.3 \mathrm{a}$ & $51.4 \mathrm{~b}$ & $56.9 \mathrm{~b}$ & $43.8 \mathrm{~b}$ & $27.8 \mathrm{~b}$ & $18.1 \mathrm{a}$ \\
\hline $\mathrm{CV}(\%)$ & 10.6 & 10.1 & 7.4 & 10.5 & 9.6 & 4.8 \\
\hline \multirow{3}{*}{ Perlakuan } & \multicolumn{6}{|c|}{ Pada Umur 6 Minggu Setelah Tanam } \\
\hline & \multicolumn{3}{|c|}{ Sisi Atas Daun } & \multicolumn{3}{|c|}{ Sisi Bawah Daun } \\
\hline & $\begin{array}{c}\text { Daun } \\
\text { Atas }\end{array}$ & $\begin{array}{l}\text { Daun } \\
\text { Tengah }\end{array}$ & $\begin{array}{c}\text { Daun } \\
\text { Bawah }\end{array}$ & $\begin{array}{c}\text { Daun } \\
\text { Atas }\end{array}$ & $\begin{array}{c}\text { Daun } \\
\text { Tengah }\end{array}$ & $\begin{array}{c}\text { Daun } \\
\text { Bawah }\end{array}$ \\
\hline $\begin{array}{l}\text { Ayunan nozzle digerakkan } \\
\text { ke depan menghadap ke } \\
\text { bawah di atas tajuk } \\
\text { tanaman }\end{array}$ & $72.9 \mathrm{~b}$ & $38.9 \mathrm{a}$ & $23.6 \mathrm{a}$ & $10.4 \mathrm{a}$ & $9.7 \mathrm{a}$ & $13.9 \mathrm{a}$ \\
\hline $\begin{array}{l}\text { Ayunan nozzle dari bawah } \\
\text { diarahkan ke tanaman } \\
\text { dengan sudut } 45^{\circ}\end{array}$ & $50.0 \mathrm{a}$ & $41.7 \mathrm{~b}$ & $37.5 \mathrm{~b}$ & $39.6 \mathrm{~b}$ & $18.1 \mathrm{~b}$ & $13.9 \mathrm{a}$ \\
\hline $\mathrm{CV}(\%)$ & 5.8 & 11.0 & 13.0 & 14.8 & 14.3 & 16.3 \\
\hline \multirow{3}{*}{ Perlakuan } & \multicolumn{6}{|c|}{ Pada Umur 8 Minggu Setelah Tanam } \\
\hline & \multicolumn{3}{|c|}{ Sisi Atas Daun } & \multicolumn{3}{|c|}{ Sisi Bawah Daun } \\
\hline & $\begin{array}{l}\text { Daun } \\
\text { Atas }\end{array}$ & $\begin{array}{l}\text { Daun } \\
\text { Tengah }\end{array}$ & $\begin{array}{c}\text { Daun } \\
\text { Bawah }\end{array}$ & $\begin{array}{l}\text { Daun } \\
\text { Atas }\end{array}$ & $\begin{array}{l}\text { Daun } \\
\text { Tengah }\end{array}$ & $\begin{array}{c}\text { Daun } \\
\text { Bawah }\end{array}$ \\
\hline $\begin{array}{l}\text { Ayunan nozzle digerakkan } \\
\text { ke depan menghadap ke } \\
\text { bawah di atas tajuk } \\
\text { tanaman }\end{array}$ & $68.8 \mathrm{~b}$ & $33.3 \mathrm{a}$ & $23.6 \mathrm{a}$ & $20.8 \mathrm{a}$ & $21.1 \mathrm{a}$ & $11.1 \mathrm{a}$ \\
\hline $\begin{array}{l}\text { Ayunan nozzle dari bawah } \\
\text { diarahkan ke tanaman } \\
\text { dengan sudut } 45^{\circ}\end{array}$ & $56.3 \mathrm{a}$ & $30.6 \mathrm{a}$ & $34.7 \mathrm{~b}$ & $29.2 \mathrm{~b}$ & $20.2 \mathrm{a}$ & $9.7 \mathrm{a}$ \\
\hline $\mathrm{CV}(\%)$ & 2.8 & 10.1 & 3.9 & 11.4 & 12.4 & 7.8 \\
\hline
\end{tabular}

Keterangan: Angka rerata perlakuan yang terletak pada kolom yang sama dan diikuti oleh huruf yang sama pula tidak menunjukkan perbedaan yang nyata menurut uji-t pada taraf $5 \%$. 


\section{Penyebaran Droplet}

Data pada Tabel 3 memperlihatkan penyebaran droplet yang merata menurut Gambar 3. Ternyata teknik penyemprotan dengan ayunan nozzle digerakkan ke depan menghadap ke bawah di atas tajuk tanaman mampu menghasilkan penyebaran droplet yang merata di semua posisi daun, tetapi hanya pada sisi atasnya saja. Sementara penyebaran droplet pada sisi bawah daun tidak ada yang merata. Dengan bertambahnya umur tanaman, daun mentimun semakin lebat. Akibatnya persentase penyebaran droplet yang merata semakin rendah. Hal itu menunjukkan bahwa penyemprotan dengan cara tersebut kurang mampu menjangkau daun-daun yang letaknya lebih tersembunyi.

Teknik penyemprotan dengan ayunan nozzle dari bawah diarahkan ke tanaman dengan sudut $45^{0}$ mampu menghasilkan penyebaran droplet di daun atas, tengah maupun bawah pada semua posisi, baik pada sisi atas maupun sisi bawah, meskipun persentase penyebaran yang merata di sisi bawah sangat rendah. Persentase penyebaran droplet pada daun sisi atas cukup stabil, sejak tanaman masih berumur 4 MST sampai umur 8 MST, berkisar antara $75.00 \%-80.56 \%$.

Persentase penyebaran droplet yang merata pada daun sisi atas pada perlakuan teknik penyemprotan dengan ayunan nozzle digerakkan ke depan menghadap ke bawah di atas tajuk tanaman lebih rendah daripada yang dihasilkan oleh perlakuan teknik penyemprotan dengan ayunan nozzle dari bawah diarahkan ke tanaman dengan sudut $45^{\circ}$. Hal ini terjadi karena pada penyemprotan dengan cara yang kedua tersebut tongkat nozzle digerakkan secara lebih fleksibel sehingga droplet dapat tersebar ke area yang lebih luas.

Menurut Beda dan Szikra (2014), sudut penyemprotan merupakan salah satu faktor penting pada saat melakukan penyemprotan pestisida dengan menggunakan pelarut air. Hal itu disebabkan akan berpengaruh terhadap penetrasi larutan semprot dan deposisi droplet (Braekman et al., 2009). Pada percobaan ini menunjukkan bahwa teknik penyemprotan dengan ayunan nozzle dari bawah diarahkan ke tanaman dengan sudut $45^{\circ}$ menghasilkan penetrasi larutan semprot dan deposisi droplet yang lebih baik.

Tabel 3. Penyebaran droplet pada daun mentimun pada perlakuan teknik penyemprotan pestisida

\begin{tabular}{|c|c|c|c|c|c|c|c|}
\hline \multirow{3}{*}{ Perlakuan } & \multirow{3}{*}{ Bagian Daun } & \multicolumn{6}{|c|}{$\begin{array}{c}\text { Penyebaran Droplet yang Merata (\%) } \\
\text { Menurut Umur Tanaman }\end{array}$} \\
\hline & & \multicolumn{2}{|c|}{$4 \mathrm{MST}$} & \multicolumn{2}{|c|}{$6 \mathrm{MST}$} & \multicolumn{2}{|c|}{$8 \mathrm{MST}$} \\
\hline & & $\begin{array}{l}\text { Sisi } \\
\text { Atas }\end{array}$ & $\begin{array}{c}\text { Sisi } \\
\text { Bawah }\end{array}$ & $\begin{array}{l}\text { Sisi } \\
\text { Atas }\end{array}$ & $\begin{array}{c}\text { Sisi } \\
\text { Bawah }\end{array}$ & $\begin{array}{l}\text { Sisi } \\
\text { Atas }\end{array}$ & $\begin{array}{c}\text { Sisi } \\
\text { Bawah }\end{array}$ \\
\hline \multirow{6}{*}{$\begin{array}{l}\text { Ayunan nozzle } \\
\text { digerakkan ke } \\
\text { depan } \\
\text { menghadap ke } \\
\text { bawah di atas } \\
\text { tajuk tanaman }\end{array}$} & Daun atas-luar & 83.33 & 0.00 & 75.00 & 0.00 & 41.67 & 0.00 \\
\hline & Daun atas-dalam & 66.67 & 0.00 & 16.67 & 0.00 & 33.33 & 0.00 \\
\hline & Daun tengah-luar & 58.33 & 0.00 & 41.67 & 0.00 & 8.33 & 0.00 \\
\hline & $\begin{array}{l}\text { Daun tengah- } \\
\text { dalam }\end{array}$ & 58.33 & 0.00 & 58.33 & 0.00 & 66.67 & 0.00 \\
\hline & Daun bawah-luar & 83.33 & 0.00 & 50.00 & 0.00 & 33.33 & 0.00 \\
\hline & $\begin{array}{l}\text { Daun bawah- } \\
\text { dalam }\end{array}$ & 75.00 & 0.00 & 25.00 & 0.00 & 25.00 & 0.00 \\
\hline \multicolumn{2}{|c|}{ Rata-rata (\%) } & 70.83 & 0.00 & 44.46 & 0.00 & 34.72 & 0.00 \\
\hline \multirow{6}{*}{$\begin{array}{l}\text { Ayunan nozzle } \\
\text { dari bawah } \\
\text { diarahkan ke } \\
\text { tanaman dengan } \\
\text { sudut } 45^{\circ}\end{array}$} & Daun atas-luar & 66.67 & 16.67 & 41.67 & 0.00 & 33.33 & 0.00 \\
\hline & & 83.33 & 8.33 & 75.00 & 0.00 & 100.00 & 0.00 \\
\hline & Daun tengah-luar & 91.67 & 0.00 & 91.67 & 8.33 & 83.33 & 0.00 \\
\hline & $\begin{array}{l}\text { Daun tengah- } \\
\text { dalam }\end{array}$ & 58.33 & 25.00 & 50.00 & 0.00 & 75.00 & 16.67 \\
\hline & Daun bawah-luar & 100.00 & 25.00 & 91.67 & 0.00 & 91.67 & 0.00 \\
\hline & $\begin{array}{l}\text { Daun bawah- } \\
\text { dalam }\end{array}$ & 83.33 & 0.00 & 100.00 & 25.00 & 91.67 & 8.33 \\
\hline Rata- & $\operatorname{ta}(\%)$ & 80.56 & 12.50 & 75.00 & 5.56 & 79.17 & 4.17 \\
\hline
\end{tabular}

Keterangan : MST $=$ minggu setelah tanam 


\section{Keefektifan Pestisida}

Selama percobaan berlangsung, jenis hama yang ditemukan menyerang tanaman mentimun ialah trips dan kutudaun. Trips ditemukan mulai menyerang pada umur 28 hari setelah tanam. Pupulasi trips dari hasil enam pengamatan pada perlakuan teknik penyemprotan dengan ayunan nozzle digerakkan ke depan menghadap ke bawah di atas tajuk tanaman lebih tinggi sebanyak lima kali dibandingkan dengan populasinya pada perlakuan lain yang diuji (Tabel 4). Populasi kutudaun pada perlakuan teknik penyemprotan dengan ayunan nozzle digerakkan ke depan menghadap ke bawah di atas tajuk tanaman juga lebih tinggi (Tabel 5). Penyakit yang ditemukan menyerang tanaman mentimun ialah penyakit embun bulu dengan tingkat serangan yang rendah (Tabel 6) dan penyakit busuk kering Alternaria (Tabel 7). Persentase serangan kedua jenis penyakit tersebut pada perlakuan teknik penyemprotan dengan ayunan nozzle digerakkan ke depan menghadap ke bawah di atas tajuk tanaman lebih tinggi. Lalat buah (Bactrocera sp). ditemukan menyerang buah dan intensitas serangannya diamati pada saat panen serta hasilnya disajikan pada Tabel 9.

Tabel 4. Populasi trips pada perlakuan teknik penyemprotan pestisida

\begin{tabular}{|c|c|c|c|c|c|c|c|c|c|}
\hline \multirow[t]{2}{*}{ Perlakuan } & \multicolumn{9}{|c|}{$\begin{array}{c}\text { Populasi Trips } \\
\text { Menurut Umur Tanaman (HST) } \\
\end{array}$} \\
\hline & 7 & 14 & 21 & 28 & 35 & 42 & 49 & 56 & 73 \\
\hline $\begin{array}{l}\text { Ayunan nozzle } \\
\text { digerakkan ke depan } \\
\text { menghadap ke bawah di } \\
\text { atas tajuk tanaman }\end{array}$ & 0.00 & 0.00 & 0.00 & $0.23 \mathrm{a}$ & $1.50 \mathrm{a}$ & $3.13 \mathrm{a}$ & $5.63 \mathrm{a}$ & $4.90 \mathrm{a}$ & $2.05 \mathrm{a}$ \\
\hline $\begin{array}{l}\text { Ayunan nozzle dari } \\
\text { bawah diarahkan ke } \\
\text { tanaman dengan sudut } 45^{\circ}\end{array}$ & 0.00 & 0.00 & 0.00 & $0.15 b$ & $1.20 \mathrm{~b}$ & $2.90 \mathrm{~b}$ & $5.25 \mathrm{a}$ & $4.00 \mathrm{~b}$ & $1.78 \mathrm{~b}$ \\
\hline $\mathrm{CV}(\%)$ & - & - & - & 7.89 & 9.87 & 10.55 & 7.84 & 6.88 & 12.15 \\
\hline
\end{tabular}

Tabel 5. Populasi kutudaun pada perlakuan teknik penyemprotan pestisida

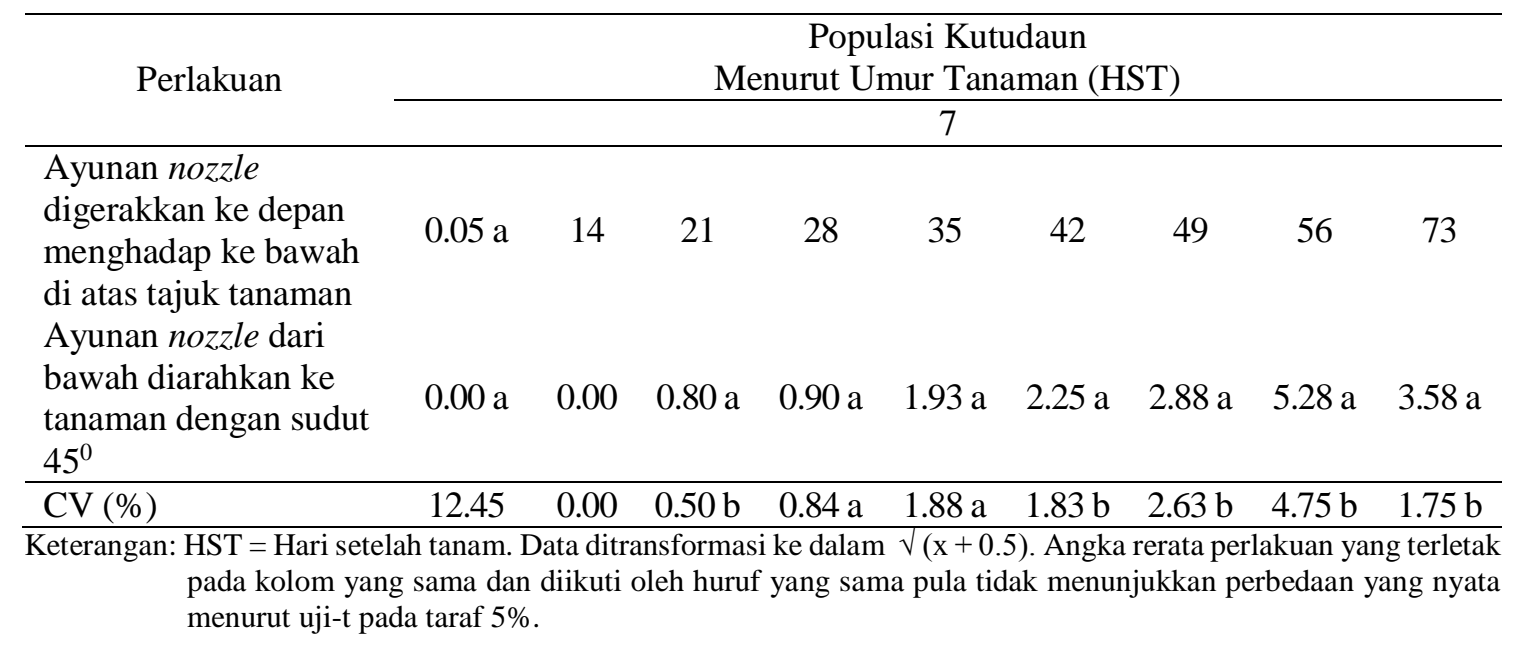


Tabel 6. Kerusakan tanaman oleh embun bulu pada perlakuan teknik penyemprotan pestisida

\begin{tabular}{|c|c|c|c|c|}
\hline \multirow[t]{2}{*}{ Perlakuan } & \multicolumn{4}{|c|}{$\begin{array}{l}\text { Persentase Kerusakan Tanaman } \\
\text { Menurut Umur Tanaman (HST) }\end{array}$} \\
\hline & \multicolumn{4}{|c|}{42} \\
\hline $\begin{array}{l}\text { Ayunan nozzle digerakkan ke depan } \\
\text { menghadap ke bawah di atas tajuk } \\
\text { tanaman }\end{array}$ & $0.50 \mathrm{a}$ & 49 & 56 & 73 \\
\hline $\begin{array}{l}\text { Ayunan nozzle dari bawah diarahkan ke } \\
\text { tanaman dengan sudut } 45^{0}\end{array}$ & $0.50 \mathrm{a}$ & $4.00 \mathrm{a}$ & $8.00 \mathrm{a}$ & 0.00 \\
\hline $\mathrm{CV}(\%)$ & 12.60 & $0.00 \mathrm{~b}$ & $4.00 \mathrm{~b}$ & 0.00 \\
\hline
\end{tabular}

Tabel 7. Kerusakan tanaman oleh Alternaria sp. pada perlakuan teknik penyemprotan pestisida

\begin{tabular}{lcccc}
\hline \multirow{2}{*}{ Perlakuan } & \multicolumn{4}{c}{$\begin{array}{c}\text { Persentase Kerusakan Tanaman } \\
\text { Menurut Umur Tanaman (HST) }\end{array}$} \\
\cline { 2 - 5 } & 42 & 49 & 56 & 73 \\
\hline $\begin{array}{l}\text { Ayunan nozzle digerakkan ke depan } \\
\text { menghadap ke bawah di atas tajuk } \\
\text { tanaman }\end{array}$ & $0.50 \mathrm{a}$ & $3.00 \mathrm{a}$ & $30.00 \mathrm{a}$ & $36.00 \mathrm{a}$ \\
$\begin{array}{l}\text { Ayunan nozzle dari bawah diarahkan } \\
\text { ke tanaman dengan sudut 45 }\end{array}$ & $0.00 \mathrm{a}$ & $3.00 \mathrm{a}$ & $13.50 \mathrm{~b}$ & $25.50 \mathrm{~b}$ \\
\hline$\quad \mathrm{CV}(\%)$ & 6.78 & 8.91 & 12.03 & 12.64 \\
\hline $\begin{array}{l}\text { Keterangan: HST }=\text { Hari setelah tanam. Data ditransformasi ke arc sin } \sqrt{\mathrm{x} .} \text {. Angka rerata perlakuan yang terletak pada } \\
\text { kolom yang sama dan diikuti oleh huruf yang sama pula tidak menunjukkan perbedaan yang nyata menurut } \\
\text { uji-t pada taraf 5\%. }\end{array}$
\end{tabular}

Berdasarkan data-data di atas, pada perlakuan teknik penyemprotan dengan ayunan nozzle digerakkan ke depan menghadap ke bawah di atas tajuk tanaman menunjukkan bahwa serangan hama dan penyakit pada perlakuan tersebut lebih tinggi. Hasil tersebut menunjukkan bahwa penyemprotan dengan cara tersebut mengakibatkan keefektipan pestisida tidak maksimal. Hassen et al. (2013), menyatakan bahwa tujuan penyemprotan pestisida ialah menempatkan bahan aktif pestisida pada tempat yang tepat untuk mengurangi populasi hama atau intensitas serangan penyakit, sehingga kehilangan hasil panen dapat ditekan. Pada Tabel 3, menunjukkan bahwa teknik penyemprotan dengan ayunan nozzle digerakkan ke depan menghadap ke bawah di atas tajuk tanaman menghasilkan tingkat penutupan droplet pada daun atas, tengah maupun bawah, tetapi penyebarannya yang merata hanya terjadi pada daun sisi atas saja. Padahal hama trips dan kutudaun serta hifa cendawan terletak pada daun sisi bawah. Dengan demikian pada perlakuan tersebut tidak seluruh hama dan penyakit terpapar oleh bahan aktif pestisida, sehingga populasi atau tingkat serangannya lebih tinggi daripada populasi atau serangannya pada perlakuan lain yang diuji. Hal itu sejalan dengan hasil penelitian yang dilakukan oleh Ebert et al. (1999) dan Gimenes et al. (2012), yaitu struktur deposit droplet berpengaruh terhadap keefektipan pestisida.

\section{Hasil Panen dan Analisis Anggaran Parsial}

Pada percobaan ini pemanenen buah mentimun dilakukan dua kali seminggu dan hasilnya disajikan pada Tabel 8. Pada perlakuan teknik penyemprotan dengan ayunan nozzle digerakkan ke depan menghadap ke bawah di atas tajuk tanaman, bobot buahnya lebih rendah, baik bobot buah sehat maupun total. Hal itu membuktikan bahwa penyemprotan dengan cara tersebut tidak mampu mengendalikan populasi hama dan serangan penyakit sehingga kehilangan hasil panen buah mentimun masih tinggi.

Jenis pestisida yang digunakan pada kedua perlakuan yang diuji adalah sama, yaitu 
abamektin, spinetoram dan klorotalonil. Perbedaan cara penyemprotan telah mengakibatkan terjadinya perbedaan volume semprot. Pada Tabel 1 dapat dilihat bahwa volume semprot yang digunakan pada perlakuan teknik penyemprotan dengan ayunan nozzle dari bawah diarahkan ke tanaman dengan sudut $45^{0}$ lebih tinggi daripada volume semprot pada perlakuan lainnya. Walaupun konsentrasi formulasi pada kedua perlakuan tersebut sama, tetapi banyaknya jumlah perstisida yang digunakan pada perlakuan teknik penyemprotan ayunan nozzle dari bawah diarahkan ke tanaman dengan sudut $45^{\circ}$ lebih tinggi jika dibandingkan dengan perlakuan teknik penyemprotan dengan ayunan nozzle digerakkan ke depan menghadap ke bawah di atas tajuk tanaman. Akibatnya biaya pestisida pada perlakuan tersebut juga lebih tinggi (Tabel 9). Namun demikian, hasil analisis anggaran parsial menunjukkan bahwa teknik penyemprotan tersebut menguntungkan, dengan nilai $\mathrm{R}>1$ (Tabel 10). Hal itu terjadi karena meskipun biaya pestisida pada perlakuan tersebut lebih tinggi, tetapi pendapatannya juga lebih tinggi akibat dari hasil panen yang lebih tinggi. Menurut Basuki (2009), karena nilai tingkat pengembalian (R) $\geq 1$, maka peluang teknologi tersebut diadopsi cukup tinggi.

Tabel 8. Pengaruh perlakuan teknik penyemprotan pestisida

\begin{tabular}{|c|c|c|c|c|c|c|}
\hline \multirow[b]{2}{*}{ Perlakuan } & \multirow{2}{*}{$\begin{array}{c}\text { Jumlah } \\
\text { Tanaman yang } \\
\text { dapat Dipanen } \\
\text { per Petak } \\
(\%)\end{array}$} & \multirow{2}{*}{$\begin{array}{l}\text { Terserang } \\
\text { oleh Lalat } \\
\text { Buah } \\
(\%)\end{array}$} & \multicolumn{2}{|c|}{$\begin{array}{l}\text { Bobot Mentimun } \\
\left(\mathrm{Kg}\left(15 \mathrm{~m}^{2}\right)\right)^{-1}\end{array}$} & \multicolumn{2}{|c|}{ ton $\mathrm{ha}^{-1}$} \\
\hline & & & $\begin{array}{l}\text { Buah } \\
\text { Sehat }\end{array}$ & Total & $\begin{array}{l}\text { Dapat } \\
\text { Dijual }\end{array}$ & Total \\
\hline $\begin{array}{l}\text { Ayunan nozzle digerakkan } \\
\text { ke depan menghadap ke } \\
\text { bawah di atas tajuk } \\
\text { tanaman }\end{array}$ & 99.38 a & $11.83 \mathrm{a}$ & $27.47 \mathrm{~b}$ & $31.17 \mathrm{~b}$ & 18.31 & 20.78 \\
\hline $\begin{array}{l}\text { Ayunan nozzle dari bawah } \\
\text { diarahkan ke tanaman } \\
\text { dengan sudut } 45^{\circ}\end{array}$ & $99.68 \mathrm{a}$ & $7.37 \mathrm{~b}$ & $31.01 \mathrm{a}$ & $33.87 \mathrm{a}$ & 20.67 & 22.56 \\
\hline $\mathrm{CV}(\%)$ & 0.80 & 6.69 & 2.08 & 1.37 & - & - \\
\hline
\end{tabular}

Tabel 9. Jenis pestisida dan biaya pestisida selama semusim tanam mentimun

\begin{tabular}{|c|c|c|c|c|c|}
\hline \multirow{3}{*}{ Perlakuan } & \multicolumn{3}{|c|}{ Pestisida yang Digunakan } & \multirow{2}{*}{\multicolumn{2}{|c|}{$\begin{array}{l}\text { Total Biaya } \\
\text { (Rp.) }\end{array}$}} \\
\hline & \multirow{2}{*}{$\begin{array}{c}\text { Abamektin } \\
\left(\mathrm{ml}\left(15 \mathrm{~m}^{2}\right)\right)^{-1}\end{array}$} & \multirow{2}{*}{$\begin{array}{l}\text { Spinetoram } \\
\left(\mathrm{ml}\left(15 \mathrm{~m}^{2}\right)\right)^{-1}\end{array}$} & \multirow{2}{*}{$\begin{array}{l}\text { Klorotalonil } \\
\left(\mathrm{g}\left(15 \mathrm{~m}^{2}\right)\right)^{-1}\end{array}$} & & \\
\hline & & & & $15 \mathrm{~m}^{2}$ & ha \\
\hline $\begin{array}{l}\text { Ayunan nozzle } \\
\text { digerakkan ke depan } \\
\text { menghadap ke } \\
\text { bawah di atas tajuk } \\
\text { tanaman }\end{array}$ & 1.32 & 1.65 & 7.25 & 5686.02 & 3790680.00 \\
\hline $\begin{array}{l}\text { Ayunan nozzle dari } \\
\text { bawah diarahkan ke } \\
\text { tanaman dengan } \\
\text { sudut } 45^{\circ}\end{array}$ & 1.83 & 2.29 & 10.08 & 7905.71 & 5270473.33 \\
\hline & & erbedaan (\%) & & & 39.04 \\
\hline
\end{tabular}


Tabel 10. Analisis anggaran parsial pada dua teknik penyemprotan yang diuji

\begin{tabular}{|c|c|c|c|}
\hline \multirow[b]{2}{*}{ Uraian } & \multicolumn{2}{|c|}{ Teknik Penyemprotan } & \multirow[b]{2}{*}{ Perbedaan } \\
\hline & $\begin{array}{c}\text { Ayunan nozzle } \\
\text { digerakkan ke depan } \\
\text { menghadap ke bawah } \\
\text { di atas tajuk tanaman }\end{array}$ & $\begin{array}{l}\text { Ayunan nozzle dari } \\
\text { bawah diarahkan } \\
\text { ke tanaman dengan } \\
\text { sudut } 45^{0}\end{array}$ & \\
\hline \multicolumn{4}{|l|}{ I. Hasil panen } \\
\hline - Bobot (kg.ha) $)^{-1}$ & 18.31 & 20.67 & -2.36 \\
\hline - Harga (Rp.kg) $)^{-1}$ & 2250 & 2250 & \\
\hline Total penerimaan (Rp.ha) ${ }^{-1}$ (TR) & 41197500.00 & 46507500.00 & - 5310000.00 \\
\hline \multicolumn{4}{|l|}{$\begin{array}{l}\text { II. Biaya berubah per hektar } \\
\text { (Rp.ha) }^{-1}\end{array}$} \\
\hline - Biaya pestisida & 3790680.00 & 5270473.33 & - 1479793.33 \\
\hline $\begin{array}{l}\text { - Bunga (1.67\%/ bulan untuk } \\
4 \text { bulan) }\end{array}$ & 253217.42 & 352067.62 & -98850.20 \\
\hline $\begin{array}{l}\text { Total biaya berubah (Rp.ha) })^{-1} \\
\text { (VC) }\end{array}$ & 4043897.42 & 5622540.95 & -1578643.53 \\
\hline Pendapatan (Rp.ha) ${ }^{-1}(\mathrm{NI})$ & 37153602.58 & 40884959.05 & -3731356.47 \\
\hline Tingkat pengembalian (R) & & 2.36 & \\
\hline
\end{tabular}

\section{KESIMPULAN}

Dari hasil percobaan ini dapat disimpulkan bahwa teknik penyemprotan pestisida pada pertanaman mentimun dengan ayunan nozzle dari bawah diarahkan ke tanaman dengan sudut $45^{\circ}$ menghasilkan tingkat penutupan larutan semprot dan penyebaran droplet yang lebih tinggi daripada yang dihasilkan oleh teknik pernyemprotan dengan posisi ayunan nozzle digerakkan ke depan menghadap ke bawah di atas tajuk tanaman, sehingga keefektipan pestisida pada perlakuan ini lebih tinggi pula. Selain itu, teknik penyemprotan tersebut secara teknis dapat mempertahankan hasil panen lebih tinggi, dan lebih menguntungkan secara ekonomis serta layak untuk diadopsi. Dengan demikian, teknologi tersebut layak direkomendasikan untuk penyemprotan pestisida pada tanaman mentimun.

\section{DAFTAR PUSTAKA}

Abbassy, M.A., M.A. Marzouk, H.M. Nasr, A.S. Mansy. 2014. Determination of imidacloprid and tetraconazole residues in cucumber plants after whitefly and powdery mildew control. SOP Transactions on Analytical Chemistry. 1(2): 1-14.
Azad, A.K., A. Sardar, N. Yesmin, M. Rahman, S. Islam. 2013. Eco-friendly pest control in cucumber (Cucumis sativus L.) field with botanical pesticides. Natural Resources. 16: 404-409.

Basuki, R.S. 2009. Analisis kelayakan teknis dan ekonomis teknologi budidaya bawang merah dengan benih biji botani dan benih umbi tradisional. J. Hort. 19(2): 213-226.

Beda, L., C. Szikra. 2014. Effect of the flow of large water droplets on the water mist sprays. YBL J. Built Env. 2(2): 2737.

Braekman, P., D. Fogue, W. Messens, M. van Labeke, J.G. Pieters, D. Nuyttens. 2009. Effect of spray application technique on spray deposition in greenhouse strawberries and tomatoes. Pest Manag. Sci. 66(2): 203-212.

Cavalieri, J.D., C.G. Raetano, R.P. Madureira, L.L. Moreira. 2015. Spraying system and travelling speed in the deposit and spectrum of droplets in cotton plant. J. Brazillian Association Agric. Eng. 35(6): 1042-1052. 
Cerruto, E., C. Aglieco, S. Failla, G. Manetto. 2013. Parameters influencing deposit estimation when using watersensitive papers. J. Agric. Eng. 49(9): 62-70.

Chiarappa, L. 1971. Crop Loss Assessment Method, FAO Manual on the evaluation and prevention of losses by pests, diseases and weeds, Commonwealth Agricultural Buereaux.

Davide, F. 2013. New application method for reducing pesticide rate/ha and cost in plant protection. Pest Manag. 24(6): 257-261.

Dhillon, M.K., R. Singh, J.S. Naresh, H.C. Sharma. 2005. The melon fruitfly, Bactrocera cucurbitae: a review of its biology and management. J. Insect Sci. 6: 40 .

Djojosumarto, P. 2008. Teknik Penyemprotan Pestisida Pertanian. Penerbit Kanisius, Yogyakarta. 211

Ebert, T.A., RA.J. Taylor, R.A. Downer, F.R. Hall. 1999. Deposit structure and efficacy of pesticide application: Trichoplusia ni control on cabbage with fipronil. Pesticide Sci. 5(8): 793 798.

Foque, D., D. Nuyttens. 2011. Effect of nozzle type and spray angle on spray deposition in ivy pot plants. Pest Manag. 67: 199-208.

Forster, W.A., G.N. Mercer, W.C. Schou. 2012. Spray droplet impaction models and their use within AGDISP software to predict retention. New Zealand Plant Protection 65: 85-92.

Fourie, P.H., M. duPreez, J.C. Brink, G.C. Schutte. 2009. The effect of run off on spray deposition and control of alternaria brown spot of mandarins. Australasian Plant Pathol. 38(2): 173182.

Gaskin, R.E., R.J. Murray, H. Krishna, A. Carpenter. 2000. Effect of adjuvants on the retention of insecticide spray on cucumber and pea foliage. New Zealand Plant Prot. 53: 55-359.

Gimenes, M.J., C.G. Raetano, M.H.F.A.D. Pogetto, E.P. Prado, R.S. Christovam, D.T. Rezende, S.I.A. Costa. 2012. Air-assistance in spray booms which have different spray volume and nozzle types for chemically controlling Spodoptera frugiperda on corn. J. Plant Prot. Res. 52(2): 247-253.

Hassen, N.S., N. Azwadi, C. Sidik, J.M. Sheriff. 2013. Effect of nozzle type, angle and pressure on spray volumetric distribution of broadcasting and banding application. J. Mechanical Engineering Res. 5(4): 76-81.

Kostik, V., B. Angelovska, E. KiroskaPetreska, B. Bauer. 2014. Determination of pesticide residue in plant-based foods from the Republic of Macedonia. J. Food and Nutrition Sci. 2(2): 124-129.

Lozowicka, B., E. Abseitova, A. Sagitov, P. Kaczynski, K. Toleubayev, A. Li. 2015. Studies of pesticide residues in tomatoes and cucumbers from Kazakhstan and associated health risks. Environ. Monit. Assess. 187(10): 609.

Munawar, A., S.W. Hameed, M. Sarwar, M. Wasim, A.S. Hashmi, M. Imran. 2013. Identification of pesticide residues in different vegetables collected from market of Lahore, Pakistan. J. Agroalimentary Processes and Technologies. 19(4): 392-398.

Salyani, M., H. Zhu, R.D. Sweeb, N. Pai. 2013. Assessment of spray distribution with water-sensitive paper. Agric. Eng. Int.CIGR J. 15(2): 101-111.

Schleier, J.J., C. Preftakes, R.K.D. Peterson. 2010. The effect of fluorescent tracers on droplet spectrum, viscosity and density of pesticide formulations. J. Env. Sci. \& Health. 45(7): 621-625. 
Shi, L., X. Zhang, H. Wu. 2011. Experimental researchon spray distribution uniformity of fan nozzle. J. Yunnan Agricultural University. 26(3): 389394.

Sugiura, M, Y. Horibe, H. Kawada, M. Takagi. 2011. Effect of different droplet size on the knockdown efficacy of directly sprayed insecticides. Pest Manag. Sci. 67: 1115-1123.

Sun, W., Q. Li, Y. Fan, Y. Wan, T. Wang, B. Cong. 2015. Effect factor analysis of spraying quality for agricultural chemicals. Int. Journal of u-and eService, Science and Technology. 8(11): 221-230.
Trdan, S., D. Znidarcic, M. Vidrih. 2007. Control of Frankliniella occidentalis on glasshouse-grown cucumbers: An efficacy comparison of foliar application of Steinernema feltiae and spraying with abamectin. Russian J. Nematology. 15(1): 25-34.

Win, D.T. 2010. Pesticides. AU. Journal Tech. 14(1): 47-55.

Yang, X., J. Zhou, X. He. 2012. Influences of nozzle types on pesticide deposition and insecticidal effect to wheat aphid. Transactions of the Chinese Society of Agricultural Engineering. 28(7): 46-50. 